OPEN ACCESS

Edited by:

Zuhong He,

Wuhan University, China

Reviewed by:

Ke Liu,

Capital Medical University, China Wenwen Liu,

Shandong University, China

${ }^{*}$ Correspondence:

Yu Sun

sunyu@hust.edu.cn

Specialty section:

This article was submitted to

Cellular Neuropathology,

a section of the journal

Frontiers in Cellular Neuroscience

Received: 14 November 2021

Accepted: 09 December 2021

Published: 05 January 2022

Citation:

Zhang L, Chen S and Sun Y (2022) Mechanism and Prevention of Spiral Ganglion Neuron

Degeneration in the Cochlea. Front. Cell. Neurosci. 15:814891. doi: 10.3389/fncel.2021.814891

\section{Mechanism and Prevention of Spiral Ganglion Neuron Degeneration in the Cochlea}

\author{
Li Zhang ${ }^{1}$, Sen Chen ${ }^{1}$ and Yu Sun ${ }^{1,2 *}$ \\ 1 Department of Otorhinolaryngology, Union Hospital, Tongji Medical College, Huazhong University of Science \\ and Technology, Wuhan, China, ${ }^{2}$ Institute of Otorhinolaryngology, Tongji Medical College, Huazhong University of Science \\ and Technology, Wuhan, China
}

Sensorineural hearing loss $(\mathrm{SNHL})$ is one of the most prevalent sensory deficits in humans, and approximately 360 million people worldwide are affected. The current treatment option for severe to profound hearing loss is cochlear implantation (Cl), but its treatment efficacy is related to the survival of spiral ganglion neurons (SGNs). SGNs are the primary sensory neurons, transmitting complex acoustic information from hair cells to second-order sensory neurons in the cochlear nucleus. In mammals, SGNs have very limited regeneration ability, and SGN loss causes irreversible hearing loss. In most cases of SNHL, SGN damage is the dominant pathogenesis, and it could be caused by noise exposure, ototoxic drugs, hereditary defects, presbycusis, etc. Tremendous efforts have been made to identify novel treatments to prevent or reverse the damage to SGNs, including gene therapy and stem cell therapy. This review summarizes the major causes and the corresponding mechanisms of SGN loss and the current protection strategies, especially gene therapy and stem cell therapy, to promote the development of new therapeutic methods.

Keywords: spiral ganglion neuron, sensorineural hearing loss, gene therapy, stem cell therapy, cochlea

\section{INTRODUCTION}

Hearing loss is one of the major health problems worldwide, affecting over $5 \%$ of the population of the world or approximately 466 million people ${ }^{1}$. Children with hearing loss have difficulties in language and cognitive development, thus affecting their school performance, ability to integrate into mainstream job markets, and overall quality of life (Wake et al., 2004; Borton et al., 2010). Hearing loss in the elderly may increase the risk of dementia and Alzheimer's disease (Lin et al., 2011). Based on the affected cochlear sites, hearing loss is generally categorized into conductive and sensorineural hearing loss (SNHL). SNHL is usually caused by irreversible damage to cells along the auditory pathway, including spiral ganglion neurons (SGNs). The major causes of SGN loss include harmful extrinsic (noise, ototoxic drugs, etc.) and intrinsic causes (genetic factors, aging, etc.). The mature sensorineural tissues of the cochlea in mammals, including hair cells (HCs) and SGNs, have very limited repair capacity and do not regenerate, so this damage is usually permanent.

The somata of SGNs reside in Rosenthal's spiral canal. Each cell body of SGNs gives rise to a peripheral process that extends toward the organ of Corti and a central process that connects

\footnotetext{
${ }^{1}$ https://www.who.int/news-room/fact-sheets/detail/deafness-and-hearing-loss
} 
together to form the auditory nerve emitting into the brain, thus establishing a point-to-point communication between the cochlear HCs and the cochlear nucleus. Human SGNs are divided into two types: type I and type II afferent neurons. Ninetyfive percent of the neuron population in the spiral ganglion consists of type I afferent neurons, which are myelinated and connect inner hair cells (IHC) with the cochlear nuclei of the brainstem (Eybalin, 1993). Each dendrite of type I afferent neurons innervates only one IHC, while each IHC receives contacts from 10 to 20 dendrites from type I afferent neurons (Eybalin, 1993). Type II afferent neurons account for only 5$10 \%$ of the neuron population (Spoendlin, 1972; Ruggero et al., 1982) and they are pseudounipolar and non-myelinated neurons (Berglund and Ryugo, 1986, 1991). Each type II afferent neuron innervates approximately 15 to 20 outer hair cells (OHCs), which are from the same row, while each $\mathrm{OHC}$ receives only one contact from one type II afferent neuron.

Until recently, the only treatments for SNHL have been hearing aids and cochlear implants, both of which are highly unnatural compared with normal sound stimulation, and they perform poorly in noisy environments. Cochlear implants are the standard therapy for severe to profound hearing loss, and their performance is variable, which is likely related to the number of residual SGNs (Seyyedi et al., 2014). No clinical therapies existed to rescue the dying SGNs or regenerate these cells once lost. Fortunately, great progress has been made in new biological therapies, such as gene therapy and stem cell therapy, providing promising perspectives for the future restoration of hearing in deaf people. This review summarizes the major causes and the related mechanisms leading to the degeneration of SGNs and discusses recent therapeutic strategies in gene therapy and stem cell therapy research to reverse SGN damage.

\section{MAJOR CAUSES AND CORRESPONDING MECHANISMS OF SPIRAL GANGLION NEURONS LOSS}

\section{Noise Exposure}

Exposure to excessive levels of sound leads to a temporary threshold shift (TTS) that can fully recover to normal or a permanent threshold shift (PTS) that fails to return to preexposure levels. The loss of afferent ribbon synapses and the degeneration of SGNs can be triggered by noise exposure (Fernandez et al., 2015). After mild noise exposure with TTS, swelling of afferent endings and the primary degeneration of SGNs were observed in a mouse model (Puel et al., 1998; Kujawa and Liberman, 2009). During the early stage of noise exposure, the quantity and quality of the ribbon synapses significantly deceased without total recovery even after several days when the hearing was fully recovered (Shi et al., 2015). This form of damage is thought to contribute to hearing difficulties in noisy environments, tinnitus, and other auditory dysfunctions (Kujawa and Liberman, 2009). However, high-intensity exposure (>100 dB sound pressure level, SPL) or repeated overstimulation leads to PTSs (Spoendlin, 1985). After overexposure, hair cell damage can be visible within minutes, while the death of SGNs is delayed by months to years (Johnsson, 1974).

Excitotoxicity is a complex process triggered by the overactivation of glutamate receptors that results in degenerative neuronal cell death (Lai et al., 2014). Type I SGNs are activated by glutamate, and excessive release of the excitatory neurotransmitter (glutamate) from IHC could lead to the death of SGNs. Excitotoxicity is thought to play an essential role in noise-induced hearing loss. SGN afferent synapse swelling after noise exposure is likely due to glutamate toxicity (Robertson, 1983; Puel et al., 1998). Excessive glutamate release after noise overstimulation leads to the overactivation of glutamate receptors on the postsynaptic membrane of SGNs. Such overactivation leads to an influx of cations such as $\mathrm{Na}^{+}$and $\mathrm{Ca}^{2+}$. Then, $\mathrm{Cl}^{-}$ and water molecules passively cross the plasma membrane, leading to edema and even death of the SGNs (Pujol and Puel, 1999; Wang et al., 2002). Administration of exogenous glutamate receptor agonists, including AMPA and kainite, to the cochlea could mimic this process (Ruel et al., 2000; Le Prell et al., 2004), while swelling of the afferent synapse could be prevented by treatment with a glutamate antagonist (Puel et al., 1998). These results suggest a contribution of excitotoxicity to SGN damage induced by noise exposure. In addition, an influx of $\mathrm{Ca}^{2+}$ into the afferent nerves of the cochlea leads to calcium-dependent caspase-mediated apoptosis by the intrinsic (mitochondriamediated) pathway (Puel et al., 1998; Pujol and Puel, 1999; Ruel et al., 2007).

\section{Toxic Drugs}

Certain therapeutic agents could cause functional impairment and cellular degeneration of SGNs. More than 130 drugs have been found to be ototoxic (Liu et al., 2011, 2012; Lanvers-Kaminsky et al., 2017). Two important classes are aminoglycoside antibiotics (Jeong et al., 2010; Wang et al., 2021) and platinum-based antineoplastic agents (Tsukasaki et al., 2000; Liu et al., 2019b, 2021), which could cause permanent hearing loss. Cisplatin, the most commonly used platinum-based antineoplastic agent and the most ototoxic drug in frequent use in the clinic (Muggia et al., 2015), results in OHC loss in a basal to apical gradient and SGN and cell loss in the stria vascularis (Schacht et al., 2012). Degeneration of SGNs caused by toxic drugs is frequently observed secondary to hair cell loss. However, Wang et al. (2003) found that the neurotoxic effects after carboplatin treatment occurred approximately 1 day before the IHCs were injured. A unique case showed that the benefit of cochlear implantation (CI) was lost due to the use of cisplatin (Harris et al., 2011). These results indicate that SGNs are the primary injury sites after treatment with platinum-based antineoplastic agents, and they are not limited to hair cell loss. However, the mechanisms of SGN damage induced by cisplatin have not been fully explained. One of these mechanisms is thought to be mediated through ROS generation, subsequently inducing calcium influx and apoptosis (Kawai et al., 2006; Mohan et al., 2014). Cisplatin also activates apoptosis by increasing the release of cytochrome c (Garcia-Berrocal et al., 2007; Jeong et al., 2007). The expression of JNK, phospho-JNK, c-Jun, and phospho-c-Jun are also increased (Jeong et al., 2010), indicating that activation of the c-Jun N-terminal kinase signaling pathway 
is involved in SGN apoptosis in response to oxidative stress. Liu et al. (2019b) found that Wnt signaling activated TIGAR, protecting SGNs against cisplatin-induced damage through the suppression of oxidative stress and apoptosis. Autophagic flux was found to be activated by PRDX1 via the PTEN/AKT signaling pathway in SGNs after cisplatin damage, attenuating ROS accumulation to mediate protective effects (Liu et al., 2021).

\section{Infections}

Infection with some viruses or bacteria, such as cytomegalovirus (CMV) and Streptococcus pneumoniae, leads to SNHL due to the degeneration of SGNs. CMV is the leading cause of congenital virus infection, and it affects around $0.5-1 \%$ of all live births worldwide, with approximately $10 \%$ of infected infants developing hearing loss (Lombardi et al., 2010; Plosa et al., 2012). A histopathological study of the human temporal bone showed that the total number of SGNs was significantly reduced in ears with congenital infectious diseases compared to normal ears (Miura et al., 2002). However, the mechanisms of the pathogenesis are still unclear. Mouse models of CMVinduced profound SNHL have shown that SGNs are preferentially infected by CMV and that the number of SGNs dramatically decreases (Juanjuan et al., 2011; Schachtele et al., 2011; Bradford et al., 2015; Ikuta et al., 2015). These results indicate that a reduction in the number of SGNs may be the major cause of congenital CMV infection-induced SNHL. Increased numbers of macrophages and CD3 + mononuclear cells were detected in the SGNs of infected mice with hearing loss (Schachtele et al., 2011; Bradford et al., 2015). High levels of ROS were found to be involved in CMV-induced profound SNHL (Schachtele et al., 2011; Zhuang et al., 2018). Multiple proinflammatory molecules, including tumor necrosis factor- $\alpha$, interleukin-6, CCL8, CXCL9, and CXCL10 were increased in CMV infection-induced SNHL (Teissier et al., 2011; Gabrielli et al., 2013; Melnick and Jaskoll, 2013; Bradford et al., 2015). Li et al. (2016) demonstrated that SGN apoptosis has an important relationship with SNHL induced by CMV infection. In addition to CMV, Streptococcus pneumonia and Mycobacterium tuberculosis infection-induced SNHL also led to a markedly decreased density of SGNs (Klein et al., 2003; Kuan et al., 2007; Perny et al., 2016).

\section{Genetic Factors}

Genetic factors play a crucial role in SNHL, including congenital and later-onset hearing loss. More than 150 genes have been identified to be directly associated with SNHL. Among the genes identified are those encoding transcription factors (POU3F4), ion channels (KCNQ1 and KCNE1), extracellular matrix components $(\mathrm{COCH})$, cytoskeletal proteins (several unconventional myosins), and proteins of unknown function (DFNA5). Mutations in these genes result in either primary and/or secondary SGN damage. Primary SGN degeneration is more likely to be observed with mutations of genes that play an important role in neuronal survival and the regulation of synaptic transmission, such as POU3F4, SLC17A8, and PJVK (Ruel et al., 2008; Brooks et al., 2020; Cheng et al., 2020). Mutations in POU3F4/Pou3f4, the encoding of a transcription factor, and POU-domain protein cause deafness in humans and mice (Kandpal et al., 1996;
Minowa et al., 1999). Pou3f4-/- mice showed disrupted radial bundle fasciculation and synapse formation (Coate et al., 2012) and degeneration of SGNs (Coate et al., 2012; Brooks et al., 2020). The hair cells and supporting cells in the Pou3f4-/mice appeared normal, indicating that the degeneration of SGNs is primary in this mouse model. Secondary SGN degeneration often occurs due to mutations in genes affecting hair cells or supporting cells. Mutations in the GJB2 gene, expressed in supporting cells, are the most common cause of hereditary hearing loss. Conditional Cx26-null mice exhibit secondary SGN degeneration resulting from the degeneration of hair cells and supporting cells (Wang et al., 2009; Takada et al., 2014). Degeneration of SGNs was observed in mice with mutations in other deafness genes, such as KCNQ1 and KCNE1 (Vetter et al., 1996; Eugene et al., 2009). In addition, hundreds of genes, including mitochondrial genes and antioxidant defense-related genes, are thought to predispose people to noise-induced, druginduced and age-related hearing loss by aggravating SGN damage (Wang and Puel, 2018).

\section{Aging}

Age-related hearing loss (ARHL) is the third most prevalent chronic medical condition affecting the elderly (LethbridgeCejku et al., 2004), and it is characterized by difficulties in speech discrimination and sound detection and localization, particularly in the presence of background noise. It is symmetric, progressive, and sensorineural, and it begins in the high-frequency region and spreads toward the low-frequency regions as age advances. SGNs are frequently lost during aging secondary to the loss of HCs (Schacht and Hawkins, 2005) as hair cells and supporting cells provide neurotrophic support, including neurotrophin-3 (NT3), brain-derived neurotrophic factor (BDNF), and glial cell linederived neurotrophic factor (GDNF) for SGN survival (Ernfors et al., 1995; Fritzsch et al., 1997; Takeno et al., 1998). However, SGN degeneration without HC loss is common among mammals during aging. The loss of SGNs is probably independent of the age-related loss of HCs. Primary and secondary degeneration of SGNs may coincide in the same cochlea (Hequembourg and Liberman, 2001). It may be impossible to separate the primary and secondary degeneration of SGNs during the early degeneration stages of aging. Oxidative metabolism is involved in age-related SGN loss. Significant age-related loss of SGN fibers has been observed prior to $\mathrm{HC}$ in mice lacking copper/zinc superoxide dismutase, the first-line defense against oxidative damage caused by ROS (Keithley et al., 2005). Mitochondria play a key role in ROS generation. It has been shown that age-related loss of SGNs in mice with mitochondrial dysfunction is more severe than in control mice (Niu et al., 2007; Yamasoba et al., 2007). In addition to ROS generation, mitochondria may also promote ARHL via apoptosis and calcium signaling pathways.

Signaling pathways that impact the aging of the whole organism could influence age-related SGN loss, as age is the most important predictor of SGN survival. Two key molecular pathways, the insulin/insulin-like growth factor-1 (IGF-1) pathway and the lipophilic/steroid hormone pathway, are closely related to the survival of SGNs. Caloric restriction 
(CR) can effectively modulate the IGF-1 pathway to prevent age-related neuronal loss of the enteric nervous system (Cowen, 2002; Thrasivoulou et al., 2006). CR was found to delay auditor brainstem response (ABR) threshold shifts during aging and ameliorate SGN degeneration in mice (Park et al., 1990; Willott et al., 1995; Someya et al., 2007; Yamasoba et al., 2007). Glucocorticoids, lipophilic/steroid hormones, have been shown to have detrimental effects on neuronal function during aging (Sapolsky et al., 1986; Miller and O'Callaghan, 2005; Landfield et al., 2007). In mice lacking the $\beta 2$ subunit of the nicotinic acetylcholine receptor, SGN loss was accelerated (Bao et al., 2005) and serum corticosterone (a major glucocorticoid) increased (Zoli et al., 1999) during ageing. Acceleration of age-related SGN loss was also found in mice lacking NF- $\kappa$ B (Lang et al., 2006) whose translocation in SGNs appears to be controlled by glucocorticoids (Tahera et al., 2006).

\section{PROTECTION AND REGENERATION OF SPIRAL GANGLION NEURONS}

Currently, there are no clinical therapies to prevent SGN degeneration or to regenerate these cells once lost. Numerous efforts have been made to explore potential therapies that could ameliorate the degeneration of SGNs. It is not surprising that agents that could interfere with the progression of SGN degeneration are promising candidates for SNHL. These pharmacological therapies include mitochondrial metabolic regulators, autophagy modulators, antioxidants or inhibitors of kinases, and apoptosis. However, there are no known drugs specifically approved by the FDA to prevent SGN degeneration or promote SGN repair. Although osmotic pumps containing neurotrophic factors (NTs) have been used to treat deaf animal models and have shown promising results, concerns about infection and the duration of efficacy restrict their widespread clinical application (Ma et al., 2019). More recent studies have focused on gene therapy and stem cell therapy, which could possibly provide long-term treatment efficacy (Liu et al., 2019a).

\section{Gene Therapy}

Gene therapy is a method that introduces a target foreign gene or gene regulatory element into target cells to replace or fix defective genes (Mulligan, 1993). Factors including vector types, administration routes, administration time, etc., have a vital role in the treatment effect. Currently, transfer vectors include viral and non-viral vectors. The most commonly used and most promising vectors in cochlear gene therapy are adenovirus (Ad)based and vector adeno-associated virus (AAV)-based vectors, as both have effective transduction of many cochlear cell types (Kesser and Lalwani, 2009; Ruan et al., 2010). The capacity of Ad vectors is large $(26-45 \mathrm{~kb})$, which greatly expands the number of target genes, while AAV vectors have limited capacity (4$5 \mathrm{~kb}$ ). AAV vectors are not associated with any known human disease, making them unique among viral vectors. In addition to choosing a proper vector, a safe and efficient administration route is required for inner ear gene therapies. The most commonly used routes for introducing delivery vectors into the inner ear of neonatal and adult animals are through the scala media, scala tympani, and the semicircular canal (Kilpatrick et al., 2011; Gassner et al., 2012; Chien et al., 2015). Some studies also delivered viral vectors in utero (Bedrosian et al., 2006; Gubbels et al., 2008). Gene therapy goals for SGNs include preventing the degeneration of SGNs and promoting the regeneration of SGNs. The most studied gene therapies in animal models to protect the SGN are NTs, such as BDNF and NT3 (Wan et al., 2014; Budenz et al., 2015; Pfingst et al., 2017). Neurotrophins regulate neuronal differentiation and survival during cochlear development (Fritzsch et al., 1999; Farinas et al., 2001; Rubel and Fritzsch, 2002; Yang et al., 2011). BDNF and NT3, mainly provided by supporting cells of the organ of Corti, have important roles in the development and maintenance of SGNs (Schecterson and Bothwell, 1994; Fritzsch et al., 1999; Stankovic et al., 2004). Loss of BDNF and NT3 support leads to the gradual degeneration of SGNs (Fritzsch et al., 1999; Alam et al., 2007).

Exogenous NT (BDNF, GDNF, NT3, CNTF, and others) administration into the cochlea can prevent precipitous SGN loss (Gillespie et al., 2003) and also promote long-term survival of SGNs (Shepherd et al., 2008; Agterberg et al., 2009; Leake et al., 2011), especially when combined with electrical stimulation (Shepherd et al., 2005; Leake et al., 2013). Several studies in deaf animal models, including guinea pigs, mice (Fukui et al., 2012), rats (Wu et al., 2011) and cats, have reported improved SGN survival with virally mediated NT expression compared to controls after acoustic trauma (Table 1). Staecker et al. (1998) reported that an HSV-1 vector containing BDNF could almost completely rescue the damaged SGNs caused by neomycin despite the destruction of all HCs. Another study demonstrated that enhanced SGN survival was observed for up to 4 weeks in aminoglycoside/diuretic-induced deafened guinea pigs with the administration of Ad-mediated transfection of GDNF compared to the controls (Yagi et al., 2000). Ad-mediated gene transfer of BDNF and NT3 also prevented SGN degeneration after aminoglycoside-induced deafness in guinea pigs (Wise et al., 2010). HSV1-mediated NT3 expression protected SGNs from degeneration caused by cisplatin-induced ototoxicity in aged mice (Bowers et al., 2002). In addition to SGN protection, gene therapy with NTs could also improve the survival and resprouting of the radial nerve fibers of SGNs (Shibata et al., 2010; Wise et al., 2010; Atkinson et al., 2012, 2014; Fukui et al., 2012; Chen et al., 2018).

Noise-induced synapse loss could be prevented with inner ear gene therapy with NTs. SGN degeneration and hearing loss in rats exposed to blast waves were prevented by gene therapy with Ad-mediated human beta-nerve growth factor gene transfer (Wu et al., 2011). Synapse damage caused by noise exposure could be prevented by Ntf3 overexpression via gene therapy (Wan et al., 2014). AAV-mediated NT3 overexpression prevented and repaired noise-induced synaptopathy (Chen et al., 2018; Hashimoto et al., 2019). Pfingst et al. (2017) also demonstrated that AAV-mediated NT3 gene therapy could prevent SGN degeneration in deafened, implanted guinea pigs.

A proper administration approach is important for SGN gene therapy. Wise et al. (2010) demonstrated that injection of vectors into the scala media resulted in more localized gene 
TABLE 1 | Studies of gene therapy for SGNs rescue in deafened animals.

\begin{tabular}{|c|c|c|c|c|c|}
\hline Animal & Damage model & $\begin{array}{l}\text { Administration } \\
\text { route }\end{array}$ & Viral vectors & Morphological protection & References \\
\hline CBA/6J mice & Neomycin & scala tympani & HSV1-BDNF & significantly improved SGNs survival & Staecker et al., 1998 \\
\hline Guinea pig & $\begin{array}{l}\text { Kanamycin }+ \\
\text { ethacrynic acid }\end{array}$ & scala tympani & Ad5-GDNF & significantly enhanced SGNs survival & Yagi et al., 2000 \\
\hline Guinea pig & $\begin{array}{l}\text { Kanamycin }+ \\
\text { ethacrynic acid }\end{array}$ & Scala media & $A A V-B D N F$ & significantly enhanced SGNs survival & Lalwani et al., 2002 \\
\hline $\begin{array}{l}\text { CBA/CaJ aging } \\
\text { mice }\end{array}$ & cisplatin & scala tympani & HSV1-NT3 & significantly improved SGNs survival & Bowers et al., 2002 \\
\hline Guinea pig & $\begin{array}{l}\text { Kanamycin }+ \\
\text { ethacrynic acid }\end{array}$ & scala tympani & $\begin{array}{l}\text { Ad-BDNF } \\
\text { Ad-CNTF }\end{array}$ & $\begin{array}{l}\text { BDNF alone and the combined BDNF and CNTF } \\
\text { treatment significantly enhanced SGN survival. CNTF did } \\
\text { not enhance the protective effect of BDNF. }\end{array}$ & Nakaizumi et al., 2004 \\
\hline Guinea pig & $\begin{array}{l}\text { Kanamycin }+ \\
\text { ethacrynic acid }\end{array}$ & scala tympani & $A d-B D N F$ & significantly preserved SGNs in the basal turns & Rejali et al., 2007 \\
\hline Guinea pig & Neomycin & scala tympani & $A d-B D N F$ & higher SGNs survival and lower $\mathrm{Cl}$ thresholds & Chikar et al., 2008 \\
\hline Rat & Kanamycin & scala tympani & AAV1-GDNF & $\begin{array}{l}\text { Significantly reduced SGNs damage and improved } \\
\text { auditory function }\end{array}$ & Liu et al., 2008 \\
\hline Guinea pig & $\begin{array}{l}\text { Kanamycin }+ \\
\text { furosemide }\end{array}$ & $\begin{array}{l}\text { scala tympani scala } \\
\text { media }\end{array}$ & $\begin{array}{l}\text { Ad5-BDNF } \\
\text { Ad5-NT3 }\end{array}$ & $\begin{array}{l}\text { significant preservation of SGNs and radial nerve fiber } \\
\text { survival }\end{array}$ & Wise et al., 2010 \\
\hline Rat & Noise exposure & scala tympani & Ad-hNGF $\beta$ & $\begin{array}{l}\text { Significant greater number of SGNs and smaller ABR } \\
\text { threshold shift }\end{array}$ & Wu et al., 2011 \\
\hline Guinea pig & $\begin{array}{l}\text { Kanamycin }+ \\
\text { furosemide }\end{array}$ & scala media & $\begin{array}{l}\text { Ad5-BDNF or } \\
\text { Ad5-NT3 }\end{array}$ & $\begin{array}{l}\text { Significant SGNs protection in the entire basal turn for the } \\
1 \text { week deaf group, in the lower basal turn for the } 4 \text { week } \\
\text { deaf group and no protection for the } 8 \text { week deaf group }\end{array}$ & Wise et al., 2011 \\
\hline Mutant mice & Pou4f3 mutant & scala media & $A d-B D N F$ & $\begin{array}{l}\text { Enhanced preservation of SGNs and pronounced } \\
\text { sprouting of nerve fiber }\end{array}$ & Fukui et al., 2012 \\
\hline Guinea pigs & $\begin{array}{l}\text { Kanamycin }+ \\
\text { furosemide }\end{array}$ & scala media & $\begin{array}{l}\text { Ad5-BDNF } \\
\text { Ad5-NT3 }\end{array}$ & $\begin{array}{l}\text { Sustain protection of SGNs and directed peripheral fiber } \\
\text { regrowth (4-11 weeks) }\end{array}$ & Atkinson et al., 2012 \\
\hline Guinea pigs & $\begin{array}{l}\text { Kanamycin }+ \\
\text { furosemide }\end{array}$ & scala tympani & Plasmid-BDNF & Regeneration of SGNs neurites & Pinyon et al., 2014 \\
\hline Guinea pigs & $\begin{array}{l}\text { Kanamycin }+ \\
\text { furosemide }\end{array}$ & scala media & $\begin{array}{l}\text { Ad5-BDNF } \\
\text { Ad5-NT3 }\end{array}$ & Long term protection of SGNs (6 months) & Atkinson et al., 2014 \\
\hline Guinea pigs & $\begin{array}{l}\text { Neomycin or } \\
\text { Kanamycin }+ \\
\text { furosemide }\end{array}$ & scala tympani & $\begin{array}{l}\text { AAV-BDNF } \\
\text { AAV-NT3 }\end{array}$ & $\begin{array}{l}\text { A transient elevation in NT levels can sustain the cochlear } \\
\text { neural substrate in the long term; BDNF was more } \\
\text { effective than NT3 in preserving SGNs }\end{array}$ & Budenz et al., 2015 \\
\hline Guinea pigs & Neomycin & scala tympani & AAV2-NT3 & Long term protection of SGNs (5-14 months) & Pfingst et al., 2017 \\
\hline Guinea pigs & Noise exposure & scala tympani & AAV8-NT3 & Significant SGNs synaptic protection & Chen et al., 2018 \\
\hline Cat & Neomycin & scala tympani & $\begin{array}{l}\text { AAV2-hBDNF } \\
\text { AAV5-GDNF }\end{array}$ & Improved SGNs and radial nerve fiber survival & Leake et al., 2019 \\
\hline
\end{tabular}

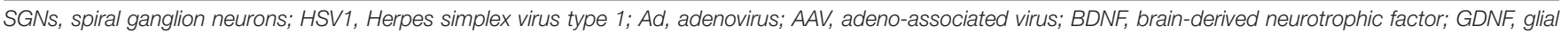
cell line-derived neurotrophic factor; NT3, neurotrophin-3; CNTF, ciliary neurotrophic factor.

expression, greater neuron survival, and more localized fiber responses than scala tympani injection. This result indicates that vector injection into the scala media may be a better method for gene therapy of SGNs. Another important factor to consider with gene therapy is the acute treatment window. Andrew et al. showed that the efficacy of SGNs protection of viralmediated NT expression diminished with an increasing duration of deafness, which indicates that there is a treatment window of gene therapy (Wise et al., 2011). Interestingly, Budenz et al. (2015) reported that BDNF was more effective in preventing SGN degeneration after deafness, while NT3 had a greater effect in eliciting the regrowth of radial nerve fibers. These results suggest that combining the overexpression of BDNF and NT3 may have a better effect on SGN protection.

Although great progress has been made in gene therapy for protecting SGNs, there are some problems that need to be solved. NT overexpression has been reported to have detrimental effects on hearing. A recent study showed that overexpression of Ntf3 in normal guinea pig cochleae led to disruption of synapses in the cochlea and hearing loss (Lee et al., 2016). Another study also found that overexpression of human GDNF in normal mice caused severe neurological symptoms and hearing loss (Akil et al., 2019). These findings indicate that extremely high levels of transgene NT expression should be avoided. Another obstacle for gene therapy application is that the gene therapy effect gradually disappears due to degeneration of the transduced cell (Atkinson et al., 2014). A long-term study on NT gene therapy showed that the efficacy of one-time injection could only last for up to 11 weeks (Atkinson et al., 2012). At 3 months after gene therapy with $B D N F$ or NT3, peripheral auditory fibers still showed considerable regrowth in the basilar membrane area compared to the controls, although the neurotrophin levels were not significantly elevated in the cochlear fluids (Budenz et al., 2015). Finally, an important limitation blocking the 
TABLE 2 | Studies of stem cell in animal models for SGN regeneration.

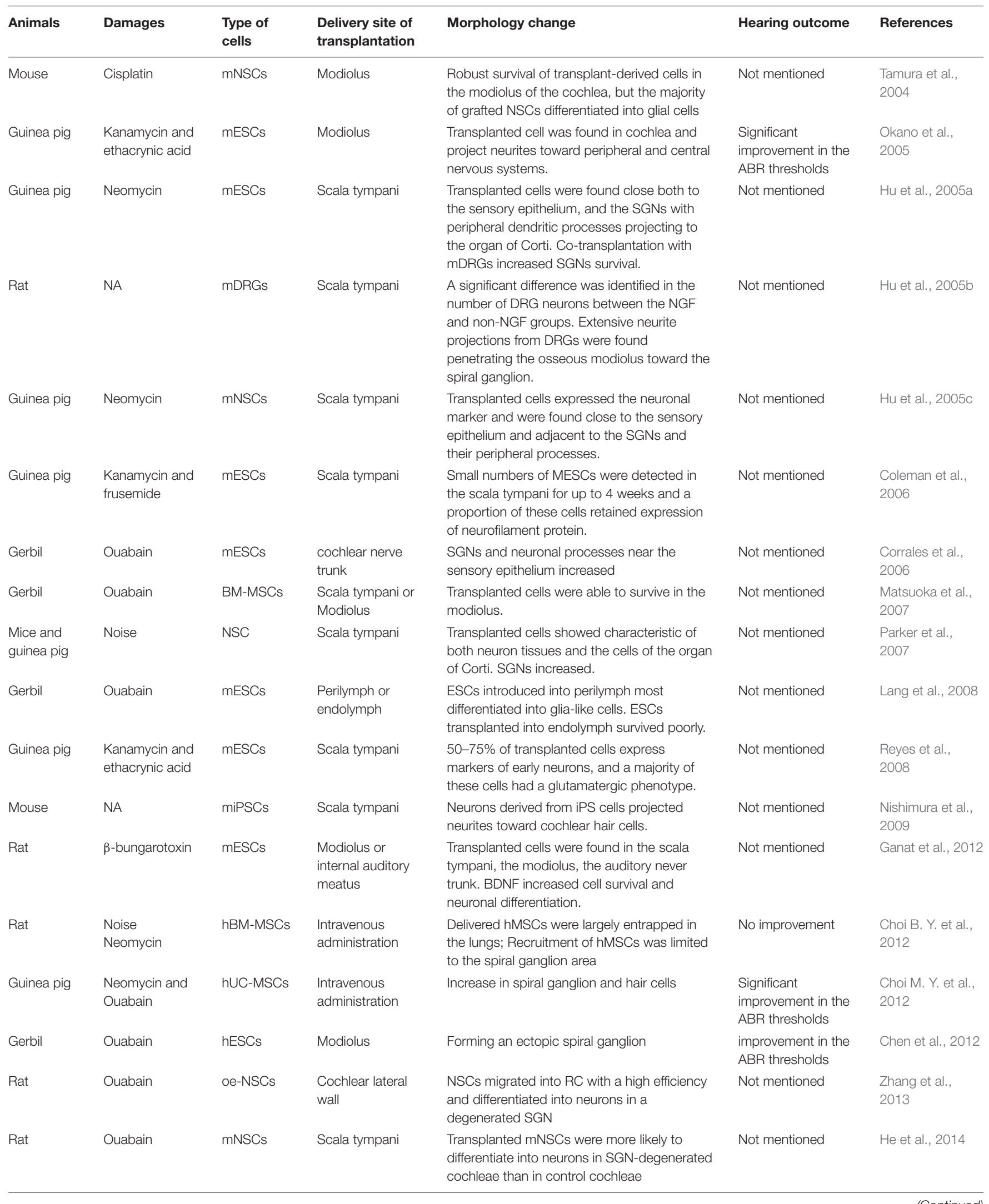


TABLE 2 | (Continued)

\begin{tabular}{|c|c|c|c|c|c|c|}
\hline Animals & Damages & $\begin{array}{l}\text { Type of } \\
\text { cells }\end{array}$ & $\begin{array}{l}\text { Delivery site of } \\
\text { transplantation }\end{array}$ & Morphology change & Hearing outcome & References \\
\hline Guinea pig & Neomycin & hMSCs & Scala tympani & Significant SGN increase & Not mentioned & Jang et al., 2015 \\
\hline $\begin{array}{l}\text { Congenital } \\
\text { deaf albino } \\
\text { pig }\end{array}$ & Hereditary & hUC-MSCs & $\begin{array}{l}\text { subarachnoid } \\
\text { cavity }\end{array}$ & $\begin{array}{l}\text { UMSC cells were detected in SGNs, basal } \\
\text { membrane and Stria Vescularis }\end{array}$ & $\begin{array}{l}\text { Detectible wave } \\
\text { change of ABR }\end{array}$ & Ma et al., 2016 \\
\hline Guinea pig & $\begin{array}{l}\text { Neomycin and } \\
\text { Ouabain }\end{array}$ & hPD-MSCs & $\begin{array}{l}\text { Intravenous } \\
\text { administration }\end{array}$ & Significant SGN increase & $\begin{array}{l}\text { improvement in the } \\
\text { ABR and DOPAE } \\
\text { thresholds }\end{array}$ & Kil et al., 2016 \\
\hline Rat & Noise & oe-NSCs & $\begin{array}{l}\text { retroauricular } \\
\text { approach }\end{array}$ & $\begin{array}{l}\text { Oe-NSC survived and migrated around the } \\
\text { SGNs in RC }\end{array}$ & $\begin{array}{l}\text { Hearing loss was } \\
\text { restored }\end{array}$ & Xu et al., 2016 \\
\hline Mouse & Neomycin & miPSCs & Scala tympani & $\begin{array}{l}\text { miPSC could differentiate into hair cell-like } \\
\text { cells and spiral ganglion-like cells }\end{array}$ & No improvement & Chen et al., 2017 \\
\hline Guinea pig & NA & hiPSCs & Scala tympani & $\begin{array}{l}\text { The survival of transplant-derived neurons } \\
\text { was achieved when inflammatory } \\
\text { responses were appropriately controlled }\end{array}$ & Not mentioned & $\begin{array}{l}\text { Ishikawa et al., } \\
2017\end{array}$ \\
\hline Guinea pig & Ouabain & hESCs & $\begin{array}{l}\text { Internal auditory } \\
\text { meatus }\end{array}$ & Transplanted cells survival was poor & $\begin{array}{l}\text { Partially recovered } \\
\text { of } A B R\end{array}$ & $\begin{array}{l}\text { Hackelberg et al., } \\
2017\end{array}$ \\
\hline Mouse & NA & miPSCs & Scala tympani & $\begin{array}{l}\text { Transplanted cells were observed in the } \\
\text { cochlear perilymph, endolymph, and } \\
\text { modiolus, and some cells expressed neural } \\
\text { cell markers. }\end{array}$ & No improvement & Zhu et al., 2018 \\
\hline Guinea pig & $\begin{array}{l}\text { Kanamycin and } \\
\text { furosemide }\end{array}$ & hMSCs & Scala tympani & $\begin{array}{l}\text { In deafened animals, the alginate-MSC } \\
\text { coating of the } \mathrm{Cl} \text { significantly prevented } \\
\text { SGN from degeneration, but the injection of } \\
\text { alginate-MSCs only did not. }\end{array}$ & No improvement & $\begin{array}{l}\text { Scheper et al., } \\
2019 a\end{array}$ \\
\hline DTR mice & DT & hESCs & Scala tympani & $\begin{array}{l}\text { Transplanted hESC-derived ONP spheroids } \\
\text { survived and neuronally differentiated into } \\
\text { otic neuronal lineages and also extended } \\
\text { neurites toward the bony wall of the cochlea }\end{array}$ & Not mentioned & $\begin{array}{l}\text { Chang et al., } \\
2020\end{array}$ \\
\hline
\end{tabular}

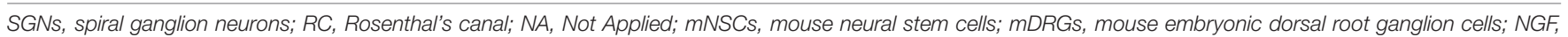

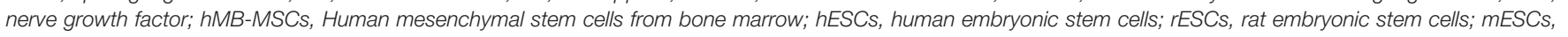

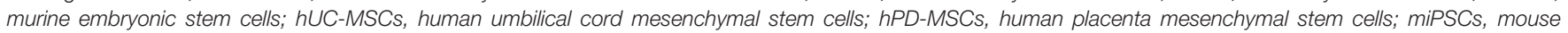
induced pluripotent stem cells; oe-NSCs, olfactory epithelium neural stem cells; hPSCs, human pluripotent stem cells.

transition into clinical practice is the lack of diagnostic tools to detect synaptopathy.

\section{Stem Cell Therapy}

Cell therapy refers to the use of live cells to repair damaged cells or to replace lost cells. Stem cells and differentiated cells can be used for these purposes (Parker, 2011). Stem cells, including embryonic stem cells (ESCs), adult stem cells (ASCs), and induced pluripotent stem cells (iPSCs), are involved in the regeneration of SGNs. There are two strategies for stem cell-based therapy: to stimulate resident stem cells within the organ of Corti to differentiate into SGNs and to supply exogenous stem cells (stem cell transplantation) into the inner ear. Theoretically, the first approach is supposed to be the best strategy for repairing or replacing damaged SGNs. Unfortunately, there is an insufficient number of resident stem cells in the adult cochlea, and they are not capable of restoring hearing.

Consequently, recent studies (Table 2) have focused on the second approach (Maharajan et al., 2021). Stem cell therapy includes stem cell differentiation into target cells in vitro and differentiated cell transplantation into the cochlea. Gunewardene et al. (2012) proposed the stepwise differentiation of ESCs and iPSCs into otic or neuronal precursors. In our opinion, the major challenge in stem cell therapy is cell transplantation, as the environment in the cochlea is hostile to the survival of foreign stem cells. Strategies to introduce exogenous neural stem cells into the cochlea include administration via the perilymph and endolymph (Lang et al., 2008) into the modiolus or the cochlear nerve (Corrales et al., 2006; Ogita et al., 2009) and into the lateral wall (Zhang et al., 2013). Although transplantation into the modiolus has shown a higher cell survival rate and increased populations of exogenous cells in Rosenthal's canal compared to transplantation into the perilymph and endolymph (Matsuoka et al., 2007; Lang et al., 2008), the transplantation process may cause hearing damage (Corrales et al., 2006; Ogita et al., 2009). The transplantation of stem cells into the sidewall of the cochlea achieved efficient results and temporary relief of auditory impairment (Zhang et al., 2013). This method may be a better choice for transplantation. Lee et al. (2017) preconditioned the scala media to reduce the potassium concentration before transplantation, thus increasing the survival of transplanted cells. However, some stem cells lose their pluripotency and differentiation ability.

Embryonic stem cells (ESCs) are pluripotent stem cells and have limitless potential to proliferate and differentiate. Studies have demonstrated that human ESCs (hESCs) are able to differentiate into otic neuronal progenitors (ONPs) and SGN-like cells. Newly differentiated SGN-like cells have genotypic and 
phenotypic SGN-specific features, and their neurites extend toward the cochlear nucleus (Matsuoka et al., 2017). Hyakumura et al. (2019) recently found that human pluripotent stem cells (hPSCs) could be derived from sensory neuronal cells, which formed synaptic connections with hair cells and cochlear nuclei in organotypic coculture. ESC-derived mouse neural progenitor cells were transplanted via a round window membrane into ouabain-deafened gerbils, and they successfully engrafted into the modiolus and formed ectopic ganglia with differentiated neuronal-type cells that projected to sensory cells in the organ of Corti (Corrales et al., 2006). Chen et al. (2012) demonstrated that transplantation of neural progenitors into adult ouabaindeafened animals rescued the auditory function of the deafened animals. Although hESCs have high proliferative capacity, ethical concerns, immunological rejection, difficulty in procurement, and tumorigenic potential limit their utilization.

ASCs are thought to be a promising resource for SGN regeneration from both ethical and patient compatibility perspectives. Some cell markers of stem cells in the olfactory epithelium are the same as some cells in the auditory epithelium, and they have good regenerative capacity in adults, making them a good source of SGNs (Graziadei and Graziadei, 1979; Roisen et al., 2001). Olfactory stem cells can survive and migrate to Rosenthal's canal after transplantation (Zhang et al., 2013; Xu et al., 2016), ameliorating noise-induced hearing impairment (Xu et al., 2016). Bone marrow stromal stem cells (Naito et al., 2004) and a purified subpopulation of glial cells expressing Sox 2 isolated from the auditory nerve also showed efficient cell migration and differentiation ability (Lang et al., 2015). However, ASCs showed far less differentiation ability than ESCs, which limited their application.

In recent years, much attention has been given to iPSCs with the development of reprogramming technology. iPSCs are adult differentiated cells that are genetically reprogrammed to form pluripotent stem cells. iPSCs can easily be obtained from the somatic cells of the patient. Thus, there is no concern about immunological rejection and fewer ethical problems. A research group demonstrated that hiPSC-derived neurons could form presynaptic connections with HCs in the in vitro coculture system (Gunewardene et al., 2016). iPSCs also have some disadvantages, such as a low proliferation rate, the tendency to differentiate into the original somatic tissue, and tumorigenicity (Nishimura et al., 2012). One main concern in regards to their tumorigenicity is the use of viral vectors during reprogramming. A recent study described a specific stepwise neural induction method for hiPSCs to eliminate undifferentiated cells from transplants, allowing the use of only terminally differentiated neurons, thus reducing the probability of tumorigenicity. First, a neural induction method was established on Matrigel-coated plates. Then, hiPSCs were differentiated into neurons on a 3D collagen matrix, and the neuron subtypes were examined. Finally, the cultured neurons were transplanted into the guinea pig cochlea (Ishikawa et al., 2017). Boddy et al. (2020) found that humaninduced pluripotent cell lines are capable of differentiating into otic cell types, including hair cells and neuronal lineages, using the non-integration approach. This technology lacks genetic integration problems, making it highly attractive in the field of regenerative medicine.

\section{CONCLUSION AND FUTURE PROSPECTS}

Different approaches are being developed for the treatment of deafness. Great progress has been made in gene therapy and stem cell therapy over the last decade. There are some problems that need to be solved, including viral safety and long-term treatment effects. Ad and AAV are widely used in cochlear gene therapy, and their safety has been confirmed in animal models. Additional research should be conducted to assess the safety and efficiency of treating humans. The treatment efficacy gradually decreases over time, so a second or even regular repeated treatments may be a solution. With regard to stem cell therapy, iPSC technology is thought to be promising. As a transplant source, autologous neurons from patient-derived iPSCs are ideal for the replacement of neurons in the injured cochlea. However, some challenges need to be overcome before application to humans, such as tumorigenesis and controlled growth of transplanted cells. Future therapies to rescue auditory function must consider multiple targets.

Combining several therapeutic strategies, for instance, stem cell delivery, gene therapy and cochlear implants, may achieve better performance. The treatment effect of cochlear implants relies at least partially on the number of surviving SGNs (Yagi et al., 2000). It is not surprising that gene therapy or stem cell therapy combined with cochlear implants could enhance the performance of cochlear implants, as gene therapy and stem cell therapy could prevent SGN degeneration. Guinea pigs treated with Ad-BDNF had a lower CI threshold and higher survival of SGNs, indicating that the combination of Ad-BDNF inoculation and electrical stimulation improved the functional measures of cochlear implant performance (Chikar et al., 2008). Scheper et al. (2019a) also showed that the alginate-MSC coating of CI significantly prevented SGN degeneration. A study demonstrated that coculture with Wnt1-expressing Schwann cells enhanced the neuronal differentiation of transplanted neural stem cells (He et al., 2014). This result reminds us that cotransplantation modified cells expressing specific cytokines along with stem cells may help us overcome the barrier of a low transplant survival rate. Genetically modified hMSCs overexpressing BDNF protect neurons significantly better from degeneration than native MSCs (Scheper et al., 2019b), which indicates that genetic modification prior to stem cell transplantation may provide a better effect. Efforts should continue toward the development of gene therapy and stem cell therapy for treating deafness.

\section{AUTHOR CONTRIBUTIONS}

YS conceived and designed the manuscript. SC and LZ wrote the manuscript. All authors contributed to the article and approved the submitted version.

\section{FUNDING}

This work was financially supported by the National Natural Science Foundation of China (Nos. 81771003 and 82071508). 


\section{REFERENCES}

Agterberg, M. J., Versnel, H., van Dijk, L. M., de Groot, J. C., and Klis, S. F. (2009). Enhanced survival of spiral ganglion cells after cessation of treatment with brain-derived neurotrophic factor in deafened guinea pigs. J. Assoc. Res. Otolaryngol. 10, 355-367. doi: 10.1007/s10162-009-0170-2

Akil, O., Blits, B., Lustig, L. R., and Leake, P. A. (2019). Virally mediated overexpression of glial-derived neurotrophic factor elicits age- and dosedependent neuronal toxicity and hearing loss. Hum. Gene Ther. 30, 88-105. doi: 10.1089/hum.2018.028

Alam, S. A., Robinson, B. K., Huang, J., and Green, S. H. (2007). Prosurvival and proapoptotic intracellular signaling in rat spiral ganglion neurons in vivo after the loss of hair cells. J. Comp. Neurol. 503, 832-852. doi: 10.1002/cne.21430

Atkinson, P. J., Wise, A. K., Flynn, B. O., Nayagam, B. A., and Richardson, R. T. (2014). Viability of long-term gene therapy in the cochlea. Sci. Rep. 4:4733. doi: $10.1038 /$ srep 04733

Atkinson, P. J., Wise, A. K., Flynn, B. O., Nayagam, B. A., Hume, C. R., O'Leary, S. J., et al. (2012). Neurotrophin gene therapy for sustained neural preservation after deafness. PLoS One 7:e52338. doi: 10.1371/journal.pone.00 52338

Bao, J., Lei, D., Du, Y., Ohlemiller, K. K., Beaudet, A. L., and Role, L. W. (2005). Requirement of nicotinic acetylcholine receptor subunit beta2 in the maintenance of spiral ganglion neurons during aging. J. Neurosci. 25, 30413045. doi: 10.1523/JNEUROSCI.5277-04.2005

Bedrosian, J. C., Gratton, M. A., Brigande, J. V., Tang, W., Landau, J., and Bennett, J. (2006). In vivo delivery of recombinant viruses to the fetal murine cochlea: transduction characteristics and long-term effects on auditory function. Mol. Ther. 14, 328-335. doi: 10.1016/j.ymthe.2006.04.003

Berglund, A. M., and Ryugo, D. K. (1986). A monoclonal antibody labels type II neurons of the spiral ganglion. Brain Res. 383, 327-332. doi: 10.1016/00068993(86)90034-x

Berglund, A. M., and Ryugo, D. K. (1991). Neurofilament antibodies and spiral ganglion neurons of the mammalian cochlea. J. Comp. Neurol. 306, 393-408. doi: $10.1002 / \mathrm{cne} .903060304$

Boddy, S. L., Romero-Guevara, R., Ji, A. R., Unger, C., Corns, L., Marcotti, W., et al. (2020). Generation of otic lineages from integration-free human-induced pluripotent stem cells reprogrammed by mRNAs. Stem Cells Int. 2020:3692937. doi: $10.1155 / 2020 / 3692937$

Borton, S. A., Mauze, E., and Lieu, J. E. (2010). Quality of life in children with unilateral hearing loss: a pilot study. Am. J. Audiol. 19, 61-72. doi: 10.1044/ 1059-0889(2010/07-0043)

Bowers, W. J., Chen, X., Guo, H., Frisina, D. R., Federoff, H. J., and Frisina, R. D. (2002). Neurotrophin-3 transduction attenuates cisplatin spiral ganglion neuron ototoxicity in the cochlea. Mol. Ther. 6, 12-18. doi: 10.1006/mthe.2002. 0627

Bradford, R. D., Yoo, Y. G., Golemac, M., Pugel, E. P., Jonjic, S., and Britt, W. J. (2015). Murine CMV-induced hearing loss is associated with inner ear inflammation and loss of spiral ganglia neurons. PLoS Pathog. 11:e1004774. doi: 10.1371/journal.ppat.1004774

Brooks, P. M., Rose, K. P., MacRae, M. L., Rangoussis, K. M., Gurjar, M., Hertzano, R., et al. (2020). Pou3f4-expressing otic mesenchyme cells promote spiral ganglion neuron survival in the postnatal mouse cochlea. J. Comp. Neurol. 528, 1967-1985. doi: 10.1002/cne.24867

Budenz, C. L., Wong, H. T., Swiderski, D. L., Shibata, S. B., Pfingst, B. E., and Raphael, Y. (2015). Differential effects of AAV.BDNF and AAV.Ntf3 in the deafened adult guinea pig ear. Sci. Rep. 5:8619. doi: 10.1038/srep08619

Chang, H. T., Heuer, R. A., Oleksijew, A. M., Coots, K. S., Roque, C. B., Nella, K. T., et al. (2020). An engineered three-dimensional stem cell niche in the inner ear by applying a nanofibrillar cellulose hydrogel with a sustained-release neurotrophic factor delivery system. Acta Biomater. 108, 111-127. doi: 10.1016/ j.actbio.2020.03.007

Chen, H., Xing, Y., Xia, L., Chen, Z., Yin, S., and Wang, J. (2018). AAV-mediated NT-3 overexpression protects cochleae against noise-induced synaptopathy. Gene Ther. 25, 251-259. doi: 10.1038/s41434-018-0012-0

Chen, J., Guan, L., Zhu, H., Xiong, S., Zeng, L., and Jiang, H. (2017). Transplantation of mouse-induced pluripotent stem cells into the cochlea for the treatment of sensorineural hearing loss. Acta Otolaryngol. 137, 1136-1142. doi: $10.1080 / 00016489.2017 .1342045$
Chen, W., Jongkamonwiwat, N., Abbas, L., Eshtan, S. J., Johnson, S. L., Kuhn, S., et al. (2012). Restoration of auditory evoked responses by human ES-cellderived otic progenitors. Nature 490, 278-282. doi: 10.1038/nature11415

Cheng, Y. F., Tsai, Y. H., Huang, C. Y., Lee, Y. S., Chang, P. C., Lu, Y. C., et al. (2020). Generation and pathological characterization of a transgenic mouse model carrying a missense PJVK mutation. Biochem. Biophys. Res. Commun. 532, 675-681. doi: 10.1016/j.bbrc.2020.07.101

Chien, W. W., McDougald, D. S., Roy, S., Fitzgerald, T. S., and Cunningham, L. L. (2015). Cochlear gene transfer mediated by adeno-associated virus: comparison of two surgical approaches. Laryngoscope 125, 2557-2564. doi: 10.1002/lary. 25317

Chikar, J. A., Colesa, D. J., Swiderski, D. L., Di Polo, A., Raphael, Y., and Pfingst, B. E. (2008). Over-expression of BDNF by adenovirus with concurrent electrical stimulation improves cochlear implant thresholds and survival of auditory neurons. Hear. Res. 245, 24-34. doi: 10.1016/j.heares.2008.08.005

Choi, B. Y., Song, J. J., Chang, S. O., Kim, S. U., and Oh, S. H. (2012). Intravenous administration of human mesenchymal stem cells after noise- or drug-induced hearing loss in rats. Acta Otolaryngol. 132(Suppl. 1), S94-S102. doi: 10.3109/ 00016489.2012 .660731

Choi, M. Y., Yeo, S. W., and Park, K. H. (2012). Hearing restoration in a deaf animal model with intravenous transplantation of mesenchymal stem cells derived from human umbilical cord blood. Biochem. Biophys. Res. Commun. 427, 629-636. doi: 10.1016/j.bbrc.2012.09.111

Coate, T. M., Raft, S., Zhao, X., Ryan, A. K., Crenshaw, E. B. III, and Kelley, M. W. (2012). Otic mesenchyme cells regulate spiral ganglion axon fasciculation through a Pou3f4/EphA4 signaling pathway. Neuron 73, 49-63. doi: 10.1016/j. neuron.2011.10.029

Coleman, B., Hardman, J., Coco, A., Epp, S., de Silva, M., Crook, J., et al. (2006). Fate of embryonic stem cells transplanted into the deafened mammalian cochlea. Cell Transplant. 15, 369-380. doi: 10.3727/000000006783981819

Corrales, C. E., Pan, L., Li, H., Liberman, M. C., Heller, S., and Edge, A. S. (2006). Engraftment and differentiation of embryonic stem cell-derived neural progenitor cells in the cochlear nerve trunk: growth of processes into the organ of Corti. J. Neurobiol. 66, 1489-1500. doi: 10.1002/neu.20310

Cowen, T. (2002). Selective vulnerability in adult and ageing mammalian neurons. Auton. Neurosci. 96, 20-24. doi: 10.1016/s1566-0702(01)00376-9

Ernfors, P., Van De Water, T., Loring, J., and Jaenisch, R. (1995). Complementary roles of BDNF and NT-3 in vestibular and auditory development. Neuron 14, 1153-1164. doi: 10.1016/0896-6273(95)90263-5

Eugene, D., Deforges, S., Vibert, N., and Vidal, P. P. (2009). Vestibular critical period, maturation of central vestibular neurons, and locomotor control. Ann. N. Y. Acad. Sci. 1164, 180-187. doi: 10.1111/j.1749-6632.2008.03727.x

Eybalin, M. (1993). Neurotransmitters and neuromodulators of the mammalian cochlea. Physiol. Rev. 73, 309-373. doi: 10.1152/physrev.1993.73.2.309

Farinas, I., Jones, K. R., Tessarollo, L., Vigers, A. J., Huang, E., Kirstein, M., et al. (2001). Spatial shaping of cochlear innervation by temporally regulated neurotrophin expression. J. Neurosci. 21, 6170-6180.

Fernandez, K. A., Jeffers, P. W., Lall, K., Liberman, M. C., and Kujawa, S. G. (2015). Aging after noise exposure: acceleration of cochlear synaptopathy in "recovered" ears. J. Neurosci. 35, 7509-7520. doi: 10.1523/JNEUROSCI.513814.2015

Fritzsch, B. I, Silos-Santiago, I., Bianchi, L. M., and Farinas, I. I. (1997). Effects of neurotrophin and neurotrophin receptor disruption on the afferent inner ear innervation. Semin. Cell Dev. Biol. 8, 277-284.

Fritzsch, B., Pirvola, U., and Ylikoski, J. (1999). Making and breaking the innervation of the ear: neurotrophic support during ear development and its clinical implications. Cell Tissue Res. 295, 369-382. doi: 10.1007/s004410051244

Fukui, H., Wong, H. T., Beyer, L. A., Case, B. G., Swiderski, D. L., Di Polo, A., et al. (2012). BDNF gene therapy induces auditory nerve survival and fiber sprouting in deaf Pou4f3 mutant mice. Sci. Rep. 2:838. doi: 10.1038/srep00838

Gabrielli, L., Bonasoni, M. P., Santini, D., Piccirilli, G., Chiereghin, A., Guerra, B., et al. (2013). Human fetal inner ear involvement in congenital cytomegalovirus infection. Acta Neuropathol. Commun. 1:63. doi: 10.1186/2051-5960-1-63

Ganat, Y. M., Calder, E. L., Kriks, S., Nelander, J., Tu, E. Y., Jia, F., et al. (2012). Identification of embryonic stem cell-derived midbrain dopaminergic neurons for engraftment. J. Clin. Invest. 122, 2928-2939. doi: 10.1172/JCI58767

Garcia-Berrocal, J. R., Nevado, J., Ramirez-Camacho, R., Sanz, R., GonzalezGarcia, J. A., Sanchez-Rodriguez, C., et al. (2007). The anticancer drug cisplatin 
induces an intrinsic apoptotic pathway inside the inner ear. Br. J. Pharmacol. 152, 1012-1020. doi: 10.1038/sj.bjp.0707405

Gassner, D., Durham, D., Pfannenstiel, S. C., Brough, D. E., and Staecker, H. (2012). Canalostomy as a surgical approach for cochlear gene therapy in the rat. Anat. Rec. (Hoboken) 295, 1830-1836. doi: 10.1002/ar.22593

Gillespie, L. N., Clark, G. M., Bartlett, P. F., and Marzella, P. L. (2003). BDNFinduced survival of auditory neurons in vivo: cessation of treatment leads to accelerated loss of survival effects. J. Neurosci. Res. 71, 785-790. doi: 10.1002/ jnr. 10542

Graziadei, P. P., and Graziadei, G. A. (1979). Neurogenesis and neuron regeneration in the olfactory system of mammals. I. Morphological aspects of differentiation and structural organization of the olfactory sensory neurons. J. Neurocytol. 8, 1-18. doi: 10.1007/BF01206454

Gubbels, S. P., Woessner, D. W., Mitchell, J. C., Ricci, A. J., and Brigande, J. V. (2008). Functional auditory hair cells produced in the mammalian cochlea by in utero gene transfer. Nature 455, 537-541. doi: 10.1038/nature07265

Gunewardene, N., Crombie, D., Dottori, M., and Nayagam, B. A. (2016). Innervation of cochlear hair cells by human induced pluripotent stem cellderived neurons in vitro. Stem Cells Int. 2016:1781202. doi: 10.1155/2016/ 1781202

Gunewardene, N., Dottori, M., and Nayagam, B. A. (2012). The convergence of cochlear implantation with induced pluripotent stem cell therapy. Stem Cell Rev. Rep. 8, 741-754. doi: 10.1007/s12015-011-9320-0

Hackelberg, S., Tuck, S. J., He, L., Rastogi, A., White, C., Liu, L., et al. (2017). Nanofibrous scaffolds for the guidance of stem cell-derived neurons for auditory nerve regeneration. PLoS One 12:e0180427. doi: 10.1371/journal.pone. 0180427

Harris, M. S., Gilbert, J. L., Lormore, K. A., Musunuru, S. A., and Fritsch, M. H. (2011). Cisplatin ototoxicity affecting cochlear implant benefit. Otol. Neurotol. 32, 969-972. doi: 10.1097/MAO.0b013e3182255893

Hashimoto, K., Hickman, T. T., Suzuki, J., Ji, L., Kohrman, D. C., Corfas, G., et al. (2019). Protection from noise-induced cochlear synaptopathy by virally mediated overexpression of NT3. Sci. Rep. 9:15362. doi: 10.1038/s41598-01951724-6

He, Y., Zhang, P. Z., Sun, D., Mi, W. J., Zhang, X. Y., Cui, Y., et al. (2014). Wnt1 from cochlear schwann cells enhances neuronal differentiation of transplanted neural stem cells in a rat spiral ganglion neuron degeneration model. Cell Transplant. 23, 747-760. doi: 10.3727/096368913X669761

Hequembourg, S., and Liberman, M. C. (2001). Spiral ligament pathology: a major aspect of age-related cochlear degeneration in C57BL/6 mice. J. Assoc. Res. Otolaryngol. 2, 118-129. doi: 10.1007/s101620010075

Hu, Z., Andang, M., Ni, D., and Ulfendahl, M. (2005a). Neural cograft stimulates the survival and differentiation of embryonic stem cells in the adult mammalian auditory system. Brain Res. 1051, 137-144. doi: 10.1016/j.brainres.2005.06.016

Hu, Z., Ulfendahl, M., and Olivius, N. P. (2005b). NGF stimulates extensive neurite outgrowth from implanted dorsal root ganglion neurons following transplantation into the adult rat inner ear. Neurobiol. Dis. 18, 184-192. doi: 10.1016/j.nbd.2004.09.010

Hu, Z., Wei, D., Johansson, C. B., Holmstrom, N., Duan, M., Frisen, J., et al. (2005c). Survival and neural differentiation of adult neural stem cells transplanted into the mature inner ear. Exp. Cell Res. 302, 40-47. doi: 10.1016/ j.yexcr.2004.08.023

Hyakumura, T., McDougall, S., Finch, S., Needham, K., Dottori, M., and Nayagam, B. A. (2019). Organotypic cocultures of human pluripotent stem cell derivedneurons with mammalian inner ear hair cells and cochlear nucleus slices. Stem Cells Int. 2019:8419493. doi: 10.1155/2019/8419493

Ikuta, K., Ogawa, H., Hashimoto, H., Okano, W., Tani, A., Sato, E., et al. (2015). Restricted infection of murine cytomegalovirus (MCMV) in neonatal mice with MCMV-induced sensorineural hearing loss. J. Clin. Virol. 69, 138-145. doi: 10.1016/j.jcv.2015.06.083

Ishikawa, M., Ohnishi, H., Skerleva, D., Sakamoto, T., Yamamoto, N., Hotta, A., et al. (2017). Transplantation of neurons derived from human iPS cells cultured on collagen matrix into guinea-pig cochleae. J. Tissue Eng. Regen. Med. 11, 1766-1778. doi: 10.1002/term.2072

Jang, S., Cho, H. H., Kim, S. H., Lee, K. H., Jun, J. Y., Park, J. S., et al. (2015). Neuralinduced human mesenchymal stem cells promote cochlear cell regeneration in deaf Guinea pigs. Clin. Exp. Otorhinolaryngol. 8, 83-91. doi: 10.3342/ceo.2015. 8.2.83
Jeong, H. J., Kim, S. J., Moon, P. D., Kim, N. H., Kim, J. S., Park, R. K., et al. (2007). Antiapoptotic mechanism of cannabinoid receptor 2 agonist on cisplatininduced apoptosis in the HEI-OC1 auditory cell line. J. Neurosci. Res. 85, 896-905. doi: 10.1002/jnr.21168

Jeong, S. W., Kim, L. S., Hur, D., Bae, W. Y., Kim, J. R., and Lee, J. H. (2010). Gentamicin-induced spiral ganglion cell death: apoptosis mediated by ROS and the JNK signaling pathway. Acta Otolaryngol. 130, 670-678. doi: 10.3109/ 00016480903428200

Johnsson, L. G. (1974). Sequence of degeneration of Corti's organ and its first-order neurons. Ann. Otol. Rhinol. Laryngol. 83, 294-303. doi: 10.1177/ 000348947408300303

Juanjuan, C., Yan, F., Li, C., Haizhi, L., Ling, W., Xinrong, W., et al. (2011). Murine model for congenital CMV infection and hearing impairment. Virol. J. 8:70. doi: 10.1186/1743-422X-8-70

Kandpal, G., Jacob, A. N., and Kandpal, R. P. (1996). Transcribed sequences encoded in the region involved in contiguous deletion syndrome that comprises $\mathrm{X}$-linked stapes fixation and deafness. Somat. Cell Mol. Genet. 22, 511-517. doi: 10.1007/BF02369442

Kawai, Y., Nakao, T., Kunimura, N., Kohda, Y., and Gemba, M. (2006). Relationship of intracellular calcium and oxygen radicals to Cisplatinrelated renal cell injury. J. Pharmacol. Sci. 100, 65-72. doi: 10.1254/jphs.fp00 50661

Keithley, E. M., Canto, C., Zheng, Q. Y., Wang, X., Fischel-Ghodsian, N., and Johnson, K. R. (2005). Cu/Zn superoxide dismutase and age-related hearing loss. Hear. Res. 209, 76-85. doi: 10.1016/j.heares.2005.06.009

Kesser, B. W., and Lalwani, A. K. (2009). Gene therapy and stem cell transplantation: strategies for hearing restoration. Adv. Otorhinolaryngol. 66, 64-86. doi: 10.1159/000218208

Kil, K., Choi, M. Y., Kong, J. S., Kim, W. J., and Park, K. H. (2016). Regenerative efficacy of mesenchymal stromal cells from human placenta in sensorineural hearing loss. Int. J. Pediatr. Otorhinolaryngol. 91, 72-81. doi: 10.1016/j.ijporl. 2016.10.010

Kilpatrick, L. A., Li, Q., Yang, J., Goddard, J. C., Fekete, D. M., and Lang, H. (2011). Adeno-associated virus-mediated gene delivery into the scala media of the normal and deafened adult mouse ear. Gene Ther. 18, 569-578. doi: $10.1038 /$ gt.2010.175

Klein, M., Koedel, U., Pfister, H. W., and Kastenbauer, S. (2003). Morphological correlates of acute and permanent hearing loss during experimental pneumococcal meningitis. Brain Pathol. 13, 123-132. doi: 10.1111/j.1750-3639. 2003.tb00012.x

Kuan, C. C., Kaga, K., and Tsuzuku, T. (2007). Tuberculous meningitis-induced unilateral sensorineural hearing loss: a temporal bone study. Acta Otolaryngol. 127, 553-557. doi: 10.1080/00016480600951418

Kujawa, S. G., and Liberman, M. C. (2009). Adding insult to injury: cochlear nerve degeneration after "temporary" noise-induced hearing loss. J. Neurosci. 29, 14077-14085. doi: 10.1523/JNEUROSCI.2845-09.2009

Lai, T. W., Zhang, S., and Wang, Y. T. (2014). Excitotoxicity and stroke: identifying novel targets for neuroprotection. Prog. Neurobiol. 115, 157-188. doi: 10.1016/ j.pneurobio.2013.11.006

Lalwani, A. K., Han, J. J., Castelein, C. M., Carvalho, G. J., and Mhatre, A. N. (2002). In vitro and in vivo assessment of the ability of adenoassociated virus-brain-derived neurotrophic factor to enhance spiral ganglion cell survival following ototoxic insult. Laryngoscope 112, 1325-1334. doi: 10. 1097/00005537-200208000-00001

Landfield, P. W., Blalock, E. M., Chen, K. C., and Porter, N. M. (2007). A new glucocorticoid hypothesis of brain aging: implications for Alzheimer's disease. Curr. Alzheimer Res. 4, 205-212. doi: 10.2174/156720507780362083

Lang, H., Schulte, B. A., Goddard, J. C., Hedrick, M., Schulte, J. B., Wei, L., et al. (2008). Transplantation of mouse embryonic stem cells into the cochlea of an auditory-neuropathy animal model: effects of timing after injury. J. Assoc. Res. Otolaryngol. 9, 225-240. doi: 10.1007/s10162-008-0119-x

Lang, H., Schulte, B. A., Zhou, D., Smythe, N., Spicer, S. S., and Schmiedt, R. A. (2006). Nuclear factor kappaB deficiency is associated with auditory nerve degeneration and increased noise-induced hearing loss. J. Neurosci. 26, 3541-3550. doi: 10.1523/JNEUROSCI.2488-05.2006

Lang, H., Xing, Y., Brown, L. N., Samuvel, D. J., Panganiban, C. H., Havens, L. T., et al. (2015). Neural stem/progenitor cell properties of glial cells in the adult mouse auditory nerve. Sci. Rep. 5:13383. doi: 10.1038/srep13383 
Lanvers-Kaminsky, C., Zehnhoff-Dinnesen, A. A., Parfitt, R., and Ciarimboli, G. (2017). Drug-induced ototoxicity: mechanisms, Pharmacogenetics, and protective strategies. Clin. Pharmacol. Ther. 101, 491-500. doi: 10.1002/ cpt.603

Le Prell, C. G., Yagi, M., Kawamoto, K., Beyer, L. A., Atkin, G., Raphael, Y., et al. (2004). Chronic excitotoxicity in the guinea pig cochlea induces temporary functional deficits without disrupting otoacoustic emissions. J. Acoust. Soc. Am. 116, 1044-1056. doi: 10.1121/1.1772395

Leake, P. A., Hradek, G. T., Hetherington, A. M., and Stakhovskaya, O. (2011). Brain-derived neurotrophic factor promotes cochlear spiral ganglion cell survival and function in deafened, developing cats. J. Comp. Neurol. 519, 1526-1545. doi: 10.1002/cne.22582

Leake, P. A., Rebscher, S. J., Dore, C., and Akil, O. (2019). AAV-Mediated neurotrophin gene therapy promotes improved survival of cochlear spiral ganglion neurons in neonatally deafened cats: comparison of AAV2-hBDNF and AAV5-hGDNF. J. Assoc. Res. Otolaryngol. 20, 341-361. doi: 10.1007/ s10162-019-00723-5

Leake, P. A., Stakhovskaya, O., Hetherington, A., Rebscher, S. J., and Bonham, B. (2013). Effects of brain-derived neurotrophic factor (BDNF) and electrical stimulation on survival and function of cochlear spiral ganglion neurons in deafened, developing cats. J. Assoc. Res. Otolaryngol. 14, 187-211. doi: 10.1007/ s10162-013-0372-5

Lee, M. Y., Hackelberg, S., Green, K. L., Lunghamer, K. G., Kurioka, T., Loomis, B. R., et al. (2017). Survival of human embryonic stem cells implanted in the guinea pig auditory epithelium. Sci. Rep. 7:46058. doi: 10.1038/srep 46058

Lee, M. Y., Kurioka, T., Nelson, M. M., Prieskorn, D. M., Swiderski, D. L., Takada, Y., et al. (2016). Viral-mediated Ntf3 overexpression disrupts innervation and hearing in nondeafened guinea pig cochleae. Mol. Ther. Methods Clin. Dev. 3:16052. doi: $10.1038 / \mathrm{mtm} .2016 .52$

Lethbridge-Cejku, M., Schiller, J. S., and Bernadel, L. (2004). Summary health statistics for U.S. adults: national health interview survey, 2002. Vital Health Stat. 10, 1-151.

Li, X., Shi, X., Wang, C., Niu, H., Zeng, L., and Qiao, Y. (2016). Cochlear spiral ganglion neuron apoptosis in neonatal mice with murine cytomegalovirusinduced sensorineural hearing loss. J. Am. Acad. Audiol. 27, 345-353. doi: 10.3766/jaaa.15061

Lin, F. R., Metter, E. J., O’Brien, R. J., Resnick, S. M., Zonderman, A. B., and Ferrucci, L. (2011). Hearing loss and incident dementia. Arch. Neurol. 68, 214-220.

Liu, W., Fan, Z., Han, Y., Lu, S., Zhang, D., Bai, X., et al. (2011). Curcumin attenuates peroxynitrite-induced neurotoxicity in spiral ganglion neurons. Neurotoxicology 32, 150-157. doi: 10.1016/j.neuro.2010.09.003

Liu, W., Fan, Z., Han, Y., Zhang, D., Li, J., and Wang, H. (2012). Intranuclear localization of apoptosis-inducing factor and endonuclease $G$ involves in peroxynitrite-induced apoptosis of spiral ganglion neurons. Neurol. Res. 34, 915-922. doi: 10.1179/1743132812Y.0000000098

Liu, W., Xu, X., Fan, Z., Sun, G., Han, Y., Zhang, D., et al. (2019b). Wnt signaling activates TP53-induced glycolysis and apoptosis regulator and protects against Cisplatin-induced spiral ganglion neuron damage in the mouse cochlea. Antioxid. Redox Signal. 30, 1389-1410. doi: 10.1089/ars.2017.7288

Liu, W., Wang, X., Wang, M., and Wang, H. (2019a). Protection of spiral ganglion neurons and prevention of auditory neuropathy. Adv. Exp. Med. Biol. 1130, 93-107. doi: 10.1007/978-981-13-6123-4_6

Liu, W., Xu, L., Wang, X., Zhang, D., Sun, G., Wang, M., et al. (2021). PRDX1 activates autophagy via the PTEN-AKT signaling pathway to protect against cisplatin-induced spiral ganglion neuron damage. Autophagy 1-23. doi: 10 . 1080/15548627.2021.1905466

Liu, Y., Okada, T., Shimazaki, K., Sheykholeslami, K., Nomoto, T., Muramatsu, S. I., et al. (2008). Protection against aminoglycoside-induced ototoxicity by regulated AAV vector-mediated GDNF gene transfer into the cochlea. Mol. Ther. 16, 474-480.

Lombardi, G., Garofoli, F., and Stronati, M. (2010). Congenital cytomegalovirus infection: treatment, sequelae and follow-up. J. Matern. Fetal Neonatal Med. 23(Suppl. 3), 45-48. doi: 10.3109/14767058.2010.506753

Ma, Y., Guo, W., Yi, H., Ren, L., Zhao, L., Zhang, Y., et al. (2016). Transplantation of human umbilical cord mesenchymal stem cells in cochlea to repair sensorineural hearing. Am. J. Transl. Res. 8, 5235-5245.
Ma, Y., Wise, A. K., Shepherd, R. K., and Richardson, R. T. (2019). New molecular therapies for the treatment of hearing loss. Pharmacol. Ther. 200, 190-209. doi: 10.1016/j.pharmthera.2019.05.003

Maharajan, N., Cho, G. W., and Jang, C. H. (2021). Therapeutic application of mesenchymal stem cells for cochlear regeneration. In Vivo 35, 13-22. doi: 10.21873/invivo. 12227

Matsuoka, A. J., Kondo, T., Miyamoto, R. T., and Hashino, E. (2007). Enhanced survival of bone-marrow-derived pluripotent stem cells in an animal model of auditory neuropathy. Laryngoscope 117, 1629-1635. doi: 10.1097/MLG. 0b013e31806bf282

Matsuoka, A. J., Morrissey, Z. D., Zhang, C., Homma, K., Belmadani, A., Miller, C. A., et al. (2017). Directed differentiation of human embryonic stem cells toward placode-derived spiral ganglion-like sensory neurons. Stem Cells Transl. Med. 6, 923-936. doi: 10.1002/sctm.16-0032

Melnick, M., and Jaskoll, T. (2013). An in vitro mouse model of congenital cytomegalovirus-induced pathogenesis of the inner ear cochlea. Birth Defects Res. A Clin. Mol. Teratol. 97, 69-78. doi: 10.1002/bdra.23105

Miller, D. B., and O'Callaghan, J. P. (2005). Aging, stress and the hippocampus. Ageing Res. Rev. 4, 123-140. doi: 10.1016/j.arr.2005.03.002

Minowa, O., Ikeda, K., Sugitani, Y., Oshima, T., Nakai, S., Katori, Y., et al. (1999). Altered cochlear fibrocytes in a mouse model of DFN3 nonsyndromic deafness. Science 285, 1408-1411. doi: 10.1126/science.285.5432.1408

Miura, M., Sando, I., Hirsch, B. E., and Orita, Y. (2002). Analysis of spiral ganglion cell populations in children with normal and pathological ears. Ann. Otol. Rhinol. Laryngol. 111, 1059-1065. doi: 10.1177/000348940211101201

Mohan, S., Smyth, B. J., Namin, A., Phillips, G., and Gratton, M. A. (2014). Targeted amelioration of cisplatin-induced ototoxicity in guinea pigs. Otolaryngol. Head Neck Surg. 151, 836-839. doi: 10.1177/0194599814544877

Muggia, F. M., Bonetti, A., Hoeschele, J. D., Rozencweig, M., and Howell, S. B. (2015). Platinum antitumor complexes: 50 years since barnett rosenberg's discovery. J. Clin. Oncol. 33, 4219-4226. doi: 10.1200/JCO.2015.60.7481

Mulligan, R. C. (1993). The basic science of gene therapy. Science 260, 926-932.

Naito, Y., Nakamura, T., Nakagawa, T., Iguchi, F., Endo, T., Fujino, K., et al. (2004). Transplantation of bone marrow stromal cells into the cochlea of chinchillas. Neuroreport 15, 1-4. doi: 10.1097/00001756-200401190-00001

Nakaizumi, T., Kawamoto, K., Minoda, R., and Raphael, Y. (2004). Adenovirusmediated expression of brain-derived neurotrophic factor protects spiral ganglion neurons from ototoxic damage. Audiol. Neurootol. 9, 135-143. doi: $10.1159 / 000077264$

Nishimura, K., Nakagawa, T., Ono, K., Ogita, H., Sakamoto, T., Yamamoto, N., et al. (2009). Transplantation of mouse induced pluripotent stem cells into the cochlea. Neuroreport 20, 1250-1254.

Nishimura, K., Nakagawa, T., Sakamoto, T., and Ito, J. (2012). Fates of murine pluripotent stem cell-derived neural progenitors following transplantation into mouse cochleae. Cell Transplant. 21, 763-771. doi: 10.3727/096368911X623907

Niu, X., Trifunovic, A., Larsson, N. G., and Canlon, B. (2007). Somatic mtDNA mutations cause progressive hearing loss in the mouse. Exp. Cell Res. 313, 3924-3934. doi: 10.1016/j.yexcr.2007.05.029

Ogita, H., Nakagawa, T., Lee, K. Y., Inaoka, T., Okano, T., Kikkawa, Y. S., et al. (2009). Surgical invasiveness of cell transplantation into the guinea pig cochlear modiolus. ORL J. Otorhinolaryngol. Relat. Spec. 71, 32-39. doi: 10. $1159 / 000165915$

Okano, T., Nakagawa, T., Endo, T., Kim, T. S., Kita, T., Tamura, T., et al. (2005). Engraftment of embryonic stem cell-derived neurons into the cochlear modiolus. Neuroreport 16, 1919-1922. doi: 10.1097/01.wnr.0000187628.38 $010.5 \mathrm{~b}$

Park, J. C., Cook, K. C., and Verde, E. A. (1990). Dietary restriction slows the abnormally rapid loss of spiral ganglion neurons in C57BL/6 mice. Hear. Res. 48, 275-279. doi: 10.1016/0378-5955(90)90067-y

Parker, M. A. (2011). Biotechnology in the treatment of sensorineural hearing loss: foundations and future of hair cell regeneration. J. Speech Lang. Hear. Res. 54, 1709-1731. doi: 10.1044/1092-4388(2011/10-0149)

Parker, M. A., Corliss, D. A., Gray, B., Anderson, J. K., Bobbin, R. P., Snyder, E. Y., et al. (2007). Neural stem cells injected into the sound-damaged cochlea migrate throughout the cochlea and express markers of hair cells, supporting cells, and spiral ganglion cells. Hear. Res. 232, 29-43. doi: 10.1016/j.heares.2007.06.007

Perny, M., Roccio, M., Grandgirard, D., Solyga, M., Senn, P., and Leib, S. L. (2016). The severity of infection determines the localization of damage and 
extent of sensorineural hearing loss in experimental pneumococcal meningitis. J. Neurosci. 36, 7740-7749. doi: 10.1523/JNEUROSCI.0554-16.2016

Pfingst, B. E., Colesa, D. J., Swiderski, D. L., Hughes, A. P., Strahl, S. B., Sinan, M., et al. (2017). Neurotrophin gene therapy in deafened ears with cochlear implants: long-term effects on nerve survival and functional measures. J. Assoc. Res. Otolaryngol. 18, 731-750. doi: 10.1007/s10162-017-0633-9

Pinyon, J. L., Tadros, S. F., Froud, K. E., Wong, Y. A. C., Tompson, I. T., Crawford, E. N., et al. (2014). Close-field electroporation gene delivery using the cochlear implant electrode array enhances the bionic ear. Sci. Transl. Med. 6:233ra54.

Plosa, E. J., Esbenshade, J. C., Fuller, M. P., and Weitkamp, J. H. (2012). Cytomegalovirus infection. Pediatr. Rev. 33, 156-163; quiz 63.

Puel, J. L., Ruel, J., Gervais d'Aldin, C., and Pujol, R. (1998). Excitotoxicity and repair of cochlear synapses after noise-trauma induced hearing loss. Neuroreport 9, 2109-2114. doi: 10.1097/00001756-199806220-00037

Pujol, R., and Puel, J. L. (1999). Excitotoxicity, synaptic repair, and functional recovery in the mammalian cochlea: a review of recent findings. Ann. N. Y. Acad. Sci. 884, 249-254. doi: 10.1111/j.1749-6632.1999.tb08646.x

Rejali, D., Lee, V. A., Abrashkin, K. A., Humayun, N., Swiderski, D. L., and Raphael, Y. (2007). Cochlear implants and ex vivo BDNF gene therapy protect spiral ganglion neurons. Hear. Res. 228, 180-187. doi: 10.1016/j.heares.2007. 02.010

Reyes, J. H., O’Shea, K. S., Wys, N. L., Velkey, J. M., Prieskorn, D. M., Wesolowski, K., et al. (2008). Glutamatergic neuronal differentiation of mouse embryonic stem cells after transient expression of neurogenin 1 and treatment with BDNF and GDNF: in vitro and in vivo studies. J. Neurosci. 28, 12622-12631. doi: 10.1523/JNEUROSCI.0563-08.2008

Robertson, D. (1983). Functional significance of dendritic swelling after loud sounds in the guinea pig cochlea. Hear. Res. 9, 263-278. doi: 10.1016/03785955(83)90031-x

Roisen, F. J., Klueber, K. M., Lu, C. L., Hatcher, L. M., Dozier, A., Shields, C. B., et al. (2001). Adult human olfactory stem cells. Brain Res. 890, 11-22.

Ruan, Q., Chen, D., Wang, Z., Chi, F., He, J., Wang, J., et al. (2010). Effects of Kir2.1 gene transfection in cochlear hair cells and application of neurotrophic factors on survival and neurite growth of co-cultured cochlear spiral ganglion neurons. Mol. Cell. Neurosci. 43, 326-339. doi: 10.1016/j.mcn.2009.12.006

Rubel, E. W., and Fritzsch, B. (2002). Auditory system development: primary auditory neurons and their targets. Annu. Rev. Neurosci. 25, 51-101. doi: 10. 1146/annurev.neuro.25.112701.142849

Ruel, J., Bobbin, R. P., Vidal, D., Pujol, R., and Puel, J. L. (2000). The selective AMPA receptor antagonist GYKI 53784 blocks action potential generation and excitotoxicity in the guinea pig cochlea. Neuropharmacology 39, 1959-1973. doi: 10.1016/s0028-3908(00)00069- 1

Ruel, J., Emery, S., Nouvian, R., Bersot, T., Amilhon, B., Van Rybroek, J. M., et al. (2008). Impairment of SLC17A8 encoding vesicular glutamate transporter3, VGLUT3, underlies nonsyndromic deafness DFNA25 and inner hair cell dysfunction in null mice. Am. J. Hum. Genet. 83, 278-292. doi: 10.1016/j.ajhg. 2008.07.008

Ruel, J., Wang, J., Rebillard, G., Eybalin, M., Lloyd, R., Pujol, R., et al. (2007). Physiology, pharmacology and plasticity at the inner hair cell synaptic complex. Hear. Res. 227, 19-27. doi: 10.1016/j.heares.2006.08.017

Ruggero, M. A., Santi, P. A., and Rich, N. C. (1982). Type II cochlear ganglion cells in the chinchilla. Hear. Res. 8, 339-356. doi: 10.1016/0378-5955(82)90023-5

Sapolsky, R. M., Krey, L. C., and McEwen, B. S. (1986). The neuroendocrinology of stress and aging: the glucocorticoid cascade hypothesis. Endocr. Rev. 7, 284-301. doi: $10.1210 /$ edrv-7-3-284

Schacht, J., and Hawkins, J. E. (2005). Sketches of otohistory. Part 9: presby[a]cusis. Audiol. Neurootol. 10, 243-247. doi: 10.1159/000086524

Schacht, J., Talaska, A. E., and Rybak, L. P. (2012). Cisplatin and aminoglycoside antibiotics: hearing loss and its prevention. Anat. Rec. (Hoboken) 295, 18371850. doi: $10.1002 /$ ar. 22578

Schachtele, S. J., Mutnal, M. B., Schleiss, M. R., and Lokensgard, J. R. (2011). Cytomegalovirus-induced sensorineural hearing loss with persistent cochlear inflammation in neonatal mice. J. Neurovirol. 17, 201-211. doi: 10.1007/s13365011-0024-7

Schecterson, L. C., and Bothwell, M. (1994). Neurotrophin and neurotrophin receptor mRNA expression in developing inner ear. Hear. Res. 73, 92-100. doi: 10.1016/0378-5955(94)90286-0
Scheper, V., Hoffmann, A., Gepp, M. M., Schulz, A., Hamm, A., Pannier, C., et al. (2019a). Stem cell based drug delivery for protection of auditory neurons in a guinea pig model of cochlear implantation. Front. Cell. Neurosci. 13:177. doi: $10.3389 /$ fncel.2019.00177

Scheper, V., Schwieger, J., Hamm, A., Lenarz, T., and Hoffmann, A. (2019b). BDNF-overexpressing human mesenchymal stem cells mediate increased neuronal protection in vitro. J. Neurosci. Res. 97, 1414-1429. doi: 10.1002/jnr. 24488

Seyyedi, M., Viana, L. M., and Nadol, J. B. Jr. (2014). Within-subject comparison of word recognition and spiral ganglion cell count in bilateral cochlear implant recipients. Otol. Neurotol. 35, 1446-1450. doi: 10.1097/MAO. 0000000000000443

Shepherd, R. K., Coco, A., and Epp, S. B. (2008). Neurotrophins and electrical stimulation for protection and repair of spiral ganglion neurons following sensorineural hearing loss. Hear. Res. 242, 100-109. doi: 10.1016/j.heares.2007. 12.005

Shepherd, R. K., Coco, A., Epp, S. B., and Crook, J. M. (2005). Chronic depolarization enhances the trophic effects of brain-derived neurotrophic factor in rescuing auditory neurons following a sensorineural hearing loss. J. Comp. Neurol. 486, 145-158. doi: 10.1002/cne.20564

Shi, L., Liu, K., Wang, H., Zhang, Y., Hong, Z., Wang, M., et al. (2015). Noise induced reversible changes of cochlear ribbon synapses contribute to temporary hearing loss in mice. Acta Otolaryngol. 135, 1093-1102. doi: 10.3109/00016489. 2015.1061699

Shibata, S. B., Cortez, S. R., Beyer, L. A., Wiler, J. A., Di Polo, A., Pfingst, B. E., et al. (2010). Transgenic BDNF induces nerve fiber regrowth into the auditory epithelium in deaf cochleae. Exp. Neurol. 223, 464-472. doi: 10.1016/j. expneurol.2010.01.011

Someya, S., Yamasoba, T., Weindruch, R., Prolla, T. A., and Tanokura, M. (2007). Caloric restriction suppresses apoptotic cell death in the mammalian cochlea and leads to prevention of presbycusis. Neurobiol. Aging 28, 1613-1622. doi: 10.1016/j.neurobiolaging.2006.06.024

Spoendlin, H. (1972). Innervation densities of the cochlea. Acta Otolaryngol. 73, 235-248.

Spoendlin, H. (1985). Histopathology of noise deafness. J. Otolaryngol. 14, $282-$ 286.

Staecker, H., Gabaizadeh, R., Federoff, H., and Van De Water, T. R. (1998). Brainderived neurotrophic factor gene therapy prevents spiral ganglion degeneration after hair cell loss. Otolaryngol. Head Neck Surg. 119, 7-13. doi: 10.1016/S01945998(98)70194-9

Stankovic, K., Rio, C., Xia, A., Sugawara, M., Adams, J. C., Liberman, M. C., et al. (2004). Survival of adult spiral ganglion neurons requires erbB receptor signaling in the inner ear. J. Neurosci. 24, 8651-8661. doi: 10.1523/JNEUROSCI. 0733-04.2004

Tahera, Y., Meltser, I., Johansson, P., Bian, Z., Stierna, P., Hansson, A. C., et al. (2006). NF-kappaB mediated glucocorticoid response in the inner ear after acoustic trauma. J. Neurosci. Res. 83, 1066-1076. doi: 10.1002/jnr. 20795

Takada, Y., Beyer, L. A., Swiderski, D. L., O’Neal, A. L., Prieskorn, D. M., Shivatzki, S., et al. (2014). Connexin 26 null mice exhibit spiral ganglion degeneration that can be blocked by BDNF gene therapy. Hear. Res. 309, 124-135. doi: 10.1016/j.heares.2013.11.009

Takeno, S., Wake, M., Mount, R. J., and Harrison, R. V. (1998). Degeneration of spiral ganglion cells in the chinchilla after inner hair cell loss induced by carboplatin. Audiol. Neurootol. 3, 281-290. doi: 10.1159/000013800

Tamura, T., Nakagawa, T., Iguchi, F., Tateya, I., Endo, T., Kim, T. S., et al. (2004). Transplantation of neural stem cells into the modiolus of mouse cochleae injured by cisplatin. Acta Otolaryngol. Suppl. 124, 65-68. doi: 10.1080/ 03655230310016780

Teissier, N., Delezoide, A. L., Mas, A. E., Khung-Savatovsky, S., Bessieres, B., Nardelli, J., et al. (2011). Inner ear lesions in congenital cytomegalovirus infection of human fetuses. Acta Neuropathol. 122, 763-774. doi: 10.1007/ s00401-011-0895-y

Thrasivoulou, C., Soubeyre, V., Ridha, H., Giuliani, D., Giaroni, C., Michael, G. J., et al. (2006). Reactive oxygen species, dietary restriction and neurotrophic factors in age-related loss of myenteric neurons. Aging Cell 5, 247-257. doi: 10.1111/j.1474-9726.2006.00214.x 
Tsukasaki, N., Whitworth, C. A., and Rybak, L. P. (2000). Acute changes in cochlear potentials due to cisplatin. Hear. Res. 149, 189-198. doi: 10.1016/ s0378-5955(00)00182-9

Vetter, D. E., Mann, J. R., Wangemann, P., Liu, J., McLaughlin, K. J., Lesage, F., et al. (1996). Inner ear defects induced by null mutation of the isk gene. Neuron 17, 1251-1264. doi: 10.1016/s0896-6273(00)80255-x

Wake, M., Hughes, E. K., Poulakis, Z., Collins, C., and Rickards, F. W. (2004). Outcomes of children with mild-profound congenital hearing loss at 7 to 8 years: a population study. Ear Hear. 25, 1-8. doi: 10.1097/01.AUD.0000111262. $12219.2 \mathrm{~F}$

Wan, G., Gomez-Casati, M. E., Gigliello, A. R., Liberman, M. C., and Corfas, G. (2014). Neurotrophin-3 regulates ribbon synapse density in the cochlea and induces synapse regeneration after acoustic trauma. Elife 3:e03564. doi: 10.7554/ eLife.03564

Wang, J., and Puel, J. L. (2018). Toward cochlear therapies. Physiol. Rev. 98, 2477-2522.

Wang, J., Ding, D., and Salvi, R. J. (2003). Carboplatin-induced early cochlear lesion in chinchillas. Hear. Res. 181, 65-72. doi: 10.1016/s0378-5955(03)0 0176-x

Wang, M., Han, Y., Wang, X., Liang, S., Bo, C., Zhang, Z., et al. (2021). Characterization of EGR-1 expression in the auditory cortex following kanamycin-induced hearing loss in mice. J. Mol. Neurosci. 71, 2260-2274. doi: 10.1007/s12031-021-01791-0

Wang, Y., Chang, Q., Tang, W., Sun, Y., Zhou, B., Li, H., et al. (2009). Targeted connexin26 ablation arrests postnatal development of the organ of Corti. Biochem. Biophys. Res. Commun. 385, 33-37. doi: 10.1016/j.bbrc.2009.05.023

Wang, Y., Hirose, K., and Liberman, M. C. (2002). Dynamics of noise-induced cellular injury and repair in the mouse cochlea. J. Assoc. Res. Otolaryngol. 3, 248-268. doi: 10.1007/s101620020028

Willott, J. F., Erway, L. C., Archer, J. R., and Harrison, D. E. (1995). Genetics of age-related hearing loss in mice. II. Strain differences and effects of caloric restriction on cochlear pathology and evoked response thresholds. Hear. Res. 88, 143-155. doi: 10.1016/0378-5955(95)00107-f

Wise, A. K., Hume, C. R., Flynn, B. O., Jeelall, Y. S., Suhr, C. L., Sgro, B. E., et al. (2010). Effects of localized neurotrophin gene expression on spiral ganglion neuron resprouting in the deafened cochlea. Mol. Ther. 18, 1111-1122. doi: $10.1038 / \mathrm{mt} .2010 .28$

Wise, A. K., Tu, T., Atkinson, P. J., Flynn, B. O., Sgro, B. E., Hume, C., et al. (2011). The effect of deafness duration on neurotrophin gene therapy for spiral ganglion neuron protection. Hear. Res. 278, 69-76. doi: 10.1016/j.heares.2011. 04.010

Wu, J., Liu, B., Fan, J., Zhu, Q., and Wu, J. (2011). Study of protective effect on rat cochlear spiral ganglion after blast exposure by adenovirus-mediated human beta-nerve growth factor gene. Am. J. Otolaryngol. 32, 8-12. doi: 10.1016/j. amjoto.2009.08.012
Xu, Y. P., Shan, X. D., Liu, Y. Y., Pu, Y., Wang, C. Y., Tao, Q. L., et al. (2016). Olfactory epithelium neural stem cell implantation restores noise-induced hearing loss in rats. Neurosci. Lett. 616, 19-25. doi: 10.1016/j.neulet.2016.01.016

Yagi, M., Kanzaki, S., Kawamoto, K., Shin, B., Shah, P. P., Magal, E., et al. (2000). Spiral ganglion neurons are protected from degeneration by GDNF gene therapy. J. Assoc. Res. Otolaryngol. 1, 315-325. doi: 10.1007/s101620010011

Yamasoba, T., Someya, S., Yamada, C., Weindruch, R., Prolla, T. A., and Tanokura, M. (2007). Role of mitochondrial dysfunction and mitochondrial DNA mutations in age-related hearing loss. Hear. Res. 226, 185-193. doi: 10. 1016/j.heares.2006.06.004

Yang, T., Kersigo, J., Jahan, I., Pan, N., and Fritzsch, B. (2011). The molecular basis of making spiral ganglion neurons and connecting them to hair cells of the organ of Corti. Hear. Res. 278, 21-33. doi: 10.1016/j.heares.2011.03.002

Zhang, P. Z., He, Y., Jiang, X. W., Chen, F. Q., Chen, Y., Shi, L., et al. (2013). Stem cell transplantation via the cochlear lateral wall for replacement of degenerated spiral ganglion neurons. Hear. Res. 298, 1-9.

Zhu, H., Chen, J., Guan, L., Xiong, S., and Jiang, H. (2018). The transplantation of induced pluripotent stem cells into the cochleae of mature mice. Int. J. Clin. Exp. Pathol. 11, 4423-4430.

Zhuang, W., Wang, C., Shi, X., Qiu, S., Zhang, S., Xu, B., et al. (2018). MCMV triggers ROS/NLRP3-associated inflammasome activation in the inner ear of mice and cultured spiral ganglion neurons, contributing to sensorineural hearing loss. Int. J. Mol. Med. 41, 3448-3456. doi: 10.3892/ijmm.201 8.3539

Zoli, M., Picciotto, M. R., Ferrari, R., Cocchi, D., and Changeux, J. P. (1999). Increased neurodegeneration during ageing in mice lacking highaffinity nicotine receptors. EMBO J. 18, 1235-1244. doi: 10.1093/emboj/18. 5.1235

Conflict of Interest: The authors declare that the research was conducted in the absence of any commercial or financial relationships that could be construed as a potential conflict of interest.

Publisher's Note: All claims expressed in this article are solely those of the authors and do not necessarily represent those of their affiliated organizations, or those of the publisher, the editors and the reviewers. Any product that may be evaluated in this article, or claim that may be made by its manufacturer, is not guaranteed or endorsed by the publisher.

Copyright (c) 2022 Zhang, Chen and Sun. This is an open-access article distributed under the terms of the Creative Commons Attribution License (CC BY). The use, distribution or reproduction in other forums is permitted, provided the original author(s) and the copyright owner(s) are credited and that the original publication in this journal is cited, in accordance with accepted academic practice. No use, distribution or reproduction is permitted which does not comply with these terms. 